\title{
Blood $\mathrm{O}_{2}$ affinity and maximal $\mathrm{O}_{2}$ consumption in elite bicycle racers
}

\author{
A. VEICSTEINAS, M. SAMAJA, M. GUSSONI, AND P. CERRETELLI \\ Department of Biomedical Sciences and Technologies, University of Milan, Milan, Italy; and \\ Department of Physiology, School of Medicine, University of Geneva, Geneva, Switzerland
}

Veicsteinas, A., M. Samaja, M. Gussoni, And P. CerreTELLI. Blood $\mathrm{O}_{2}$ affinity and maximal $\mathrm{O}_{2}$ consumption in elite bicycle racers. J. Appl. Physiol.: Respirat. Environ. Exercise Physiol. 57(1): 52-58, 1984.-The $\mathrm{Po}_{2}$ at which hemoglobin is half-saturated with $\mathrm{O}_{2}\left(\mathrm{P}_{50}\right)$ at $37^{\circ} \mathrm{C}, \mathrm{PCO}_{2}=42$ Torr, measured $\mathrm{pH}$ and 2,3-diphosphoglycerate-to-hemoglobin concentration ratio ([2,3-DPG]/[Hb]) values, Hill's coefficient $(n)$ at rest, and maximal $\mathrm{O}_{2}$ consumption $\left(\dot{\mathrm{V}}_{2 \text { max }}\right)$ were determined in 11 world-class professional bicycle racers off-season (control, C), after 3 mo of $3 \mathrm{~h}$ daily training (preseason, $\operatorname{PrS}$ ), and after additional 6 mo of competitions (competitive season, CoS). The results indicate that the $\mathrm{P}_{50}$ observed in trained athletes was the same as that of a comparable group of sedentary subjects (Sed) under the same conditions of $\mathrm{pH}, \mathrm{PCO}_{2}$, and [2,3-DPG]/ $[\mathrm{Hb}]$ and was similar to that obtained after "normalization" in respect to $\mathrm{pH}$ and the $[2,3-\mathrm{DPG}] /[\mathrm{Hb}] ;[2,3-\mathrm{DPG}] /[\mathrm{Hb}]$ increased as a function of training from 0.72 to $0.95(P<0.001)$; the slope of the central portion of the $\mathrm{O}_{2}$ equilibrium curve (OEC) was nearly unaffected by endurance training as indicated by the $n$ value $\left(n_{\mathrm{CoS}}=2.70 \pm 0.08 ; n_{\text {Sed }}=2.65 \pm 0.08\right)$; and $\mathrm{VO}_{2 \text { max }}$ increased in the course of training 7 and $9 \%(P<$ 0.001 ), respectively, when expressed in absolute units or per kilogram body weight. The $\mathrm{VO}_{2 \text { max }}$ predicted on the basis of a computer simulation does not increase significantly as a consequence of the measured rise in [2,3-DPG]. Therefore, the observed increase of $\dot{\mathrm{V}}_{2 \text { max }}$ cannot be explained with adaptive changes of the OEC. The present results differ from previous findings reported in other types of athletes.

Hill's coefficient in endurance athletes; 2,3-diphosphoglycerate-to-hemoglobin concentration ratio; oxygen half-saturation pressure

IN ORDINARY CONDITIONS the maximal aerobic power of humans appears to be primarily limited by the circulation (for a review, see Ref. 22) as opposed to ventilatory mechanics and pulmonary gas exchange (6) and tissue oxidative capacity (14). However, it is still controversial whether collateral factors such as change of the hemoglobin $(\mathrm{Hb})-\mathrm{O}_{2}$ affinity might be responsible for the fine tuning of the $\mathrm{O}_{2}$ transport system, particularly under heavy metabolic stress. In a survey of the literature, standard $\mathrm{P}_{50}\left(\mathrm{Po}_{2}\right.$ at which $\mathrm{Hb}$ is half-saturated with $\left.\mathrm{O}_{2}\right)$ of trained subjects appears to be constant or slightly increased $(3,4,20)$, whereas the concentration of 2,3diphosphoglycerate $(2,3-\mathrm{DPG})$ and $[2,3-\mathrm{DPG}] /[\mathrm{Hb}]$ are generally higher compared with those of sedentary control individuals $(3,21,27)$. Moreover, a decrease of the $\mathrm{Hb}-\mathrm{O}_{2}$ affinity has been recently claimed that cannot be explained by the influence of any known factor (4). In the above studies, subject characteristics, exercise mode intensity and duration, and training procedures are quite variable, so that a conclusive statement on the $\mathrm{Hb}-\mathrm{O}_{2}$ affinity of highly trained individuals cannot be made.

To gain insight into this aspect of blood $\mathrm{O}_{2}$ transport and, in particular, to quantitate the separate role of 2,3 DPG, measurements of $\mathrm{P}_{50}$ and its allosteric effectors (i.e., $\mathrm{H}^{+}, \mathrm{CO}_{2}$, and 2,3-DPG) were carried out in athletic subjects, whose $\mathrm{O}_{2}$ transport system should be optimized as a consequence of the prolonged exercise stress. The subjects for this study were 11 elite professional road bicycle racers, including the 1982 world champion and 3 athletes who were within the first 7 classified at the 1980 world championship. Bicyclists represent an unique group among endurance athletes because of their peculiar working schedule that includes up to $6 \mathrm{~h}$ daily exercise over several months. Their mixed venous blood $\mathrm{Po}_{2}$ is at 20-25 Torr corresponding to $40-50 \% \mathrm{Hb}^{-} \mathrm{O}_{2}$ saturation over long periods of time and thus their average $\mathrm{Hb}$ desaturation level is comparable to that of high-altitude natives or acclimatized lowlanders at $\simeq 5,000 \mathrm{~m}$ above sea level but with normal arterial saturation.

Since the regulation of the $\mathrm{O}_{2}$-carrying system may be different in these highly selected individuals compared with other endurance athletes and may vary as a function of time and cumulated exercise, a longitudinal study was carried out over a 9-mo training period aimed at describing the characteristics and the adaptations of the $\mathrm{Hb}-\mathrm{O}_{2}$ transport system as assessed from measurements of $\mathrm{P}_{50}$ and of its regulators, following the evolution of the maximal aerobic power $\left(\mathrm{Vo}_{2 \text { max }}\right)$ over the training season, and identifying the factors responsible for the change of maximal aerobic performance.

It will be seen that after training elite endurance athletes undergo a significant $(30 \%)$ increase of [2,3DPG] $/[\mathrm{Hb}]$ accompanied by a slight nonsignificant increase of $\mathrm{P}_{50}$ and a significant $(7 \%)$ increase of $\mathrm{V}_{2 \text { max }}$. A computer simulation wherein $[2,3-\mathrm{DPG}] /[\mathrm{Hb}]$ was taken as the independent variable (all other cofactors of $\mathrm{Hb}-\mathrm{O}_{2}$ being constant) indicates that this cofactor of $\mathrm{Hb}$ oxygenation is not responsible for the observed increase of $\mathrm{V}_{0_{\text {max }}}$ with training.

\section{MATERIALS AND METHODS}

Eleven world-class professional male bicyclists, after giving their informed consent, participated in this study. 
TABLE 1. Anthropometric and some hematologic data of subjects

\begin{tabular}{lcccccc}
\hline $\begin{array}{l}\text { Level of } \\
\text { Activity }\end{array}$ & Age, yr & $\begin{array}{c}\text { Body } \\
\mathrm{Wt}, \\
\mathrm{kg}\end{array}$ & $\begin{array}{c}\mathrm{RBC}, \\
\times 10^{6} \cdot \mu \mathrm{l}^{-1}\end{array}$ & $\begin{array}{c}{[\mathrm{Hb}],} \\
\mathrm{g} \cdot \mathrm{dl}^{-1}\end{array}$ & $\begin{array}{c}\mathrm{Hct}, \\
\%\end{array}$ & $\begin{array}{c}\mathrm{MCHC}, \\
\mathrm{g} \cdot \mathrm{dl}^{-1}\end{array}$ \\
\hline \multicolumn{7}{c}{ Athletes $(N=11)$} \\
$\mathrm{C}$ & 27.1 & 72.0 & 4.6 & 14.5 & 45.0 & 32.3 \\
& \pm 4.4 & \pm 6.0 & \pm 0.2 & \pm 0.7 & \pm 1.6 & \pm 1.2 \\
$\operatorname{PrS}$ & 27.4 & 70.9 & 4.6 & 15.5 & 45.8 & 33.6 \\
& \pm 4.4 & \pm 6.5 & \pm 0.2 & \pm 0.7 & \pm 1.4 & \pm 1.1 \\
$\mathrm{CoS}$ & 27.9 & 70.4 & 4.7 & 15.1 & 45.1 & 33.6 \\
& \pm 4.4 & \pm 7.0 & \pm 0.2 & \pm 1.1 & \pm 2.4 & \pm 1.9 \\
& \multicolumn{7}{c}{ Sedentary subjects $(N=20)$} \\
Sed & 31.1 & 69.9 & 4.6 & 15.5 & 45.0 & 34.5 \\
& \pm 6 & \pm 10.1 & \pm 0.3 & \pm 0.9 & \pm 1.8 & \pm 0.7 \\
\hline
\end{tabular}

Values are means $\pm \mathrm{SD}$. $N$, no. of subjects. Level of activity: C, offseason (control); PrS, preseason; CoS, competitive season; Sed, sedentary. RBC, red blood cells; [Hb], hemoglobin concentration; Hct, hematocrit; $\mathrm{MCHC}$, mean corpuscular $\mathrm{Hb}$ concentration.

The subjects' physical characteristics and hematologic data are shown in Table 1. Three series of measurements were carried out: 1) off-season (control, C), i.e., 3 mo after the last competition when physical activity consisted of only four 30-min sessions/wk; 2) after 3 mo of training (preseason, PrS) consisting in an average $4 \mathrm{~h}$ daily bicycling; and 3) after additional 6 mo of $6 \mathrm{~h}$ daily training or competitive racing (competitive season, $\mathrm{CoS}$ ), i.e., after a total of 9 mo of physical activity. It may be estimated that all subjects during the period preceding CoS had covered a distance of at least $40,000 \mathrm{~km}$. To standardize methods and procedures, a group of 20 sedentary nonsmoking male subjects (Sed) of the same age chosen among students and members of the department was also investigated.

Hematologic measurements. All tests were carried out in the morning after a light breakfast. Blood samples were taken at rest from the antecubital vein about 30 min after the subjects arrived at the laboratory. The blood samples were heparinized and stored at $0^{\circ} \mathrm{C}$. Analyses were performed in duplicate within $6 \mathrm{~h}$ of sampling. Red blood cell (RBC) counts, [Hb], and hematocrit (Hct) were determined by standard laboratory procedures. Experimental $\mathrm{P}_{50}, \mathrm{pH}$, and [2,3-DPG] were determined after $25 \mathrm{~min}$ of tonometry at $37^{\circ} \mathrm{C}, \mathrm{PCO}_{2}=42$ Torr. The measurements were performed as described by Samaja et al. (24). Hill's coefficient $n$ was determined for five athletes and all sedentary subjects, measuring the $\mathrm{O}_{2}$ saturation in the range $30-70 \%$ at four $\mathrm{PO}_{2}$ values. "Normalization" of the $\mathrm{P}_{50}$ values was performed comparing the experimental data with the values observed in a reference sedentary population under the same conditions of $\mathrm{PCO}_{2}, \mathrm{pH}$, and $[2,3-\mathrm{DPG}] /[\mathrm{Hb}]$ following the procedure described by Samaja et al. (23).

Metabolic measurements. Submaximal and maximal $\mathrm{V}_{2}$ measurements were carried out while subjects pedaled on a Monark (Varberg, Sweden) bicycle ergometer customized with individual saddles and handlebars. Similar measurements were also made for seven of the athletes performing on a treadmill. For the bicycle tests the subjects were free to keep their spontaneous pedaling rates, which were always found to be in the range $80-90$ rpm. Gas exchange measurements were made by standard open-circuit methods. $\mathrm{O}_{2}$ and $\mathrm{CO}_{2}$ concentrations were determined by a rapid oximeter (Beckman OM-11) and an infrared $\mathrm{CO}_{2}$ analyzer (Beckman LB-2), respectively. Heart rate (HR) was recorded by cardiotachograph. Two submaximal work loads corresponding to estimated $\mathrm{VO}_{2}$ levels between 50 and $80 \% \mathrm{VO}_{2 \max }$ were imposed on the athletes on both the bike and the treadmill. $\mathrm{VO}_{2 \max }$ was then determined during the performance with supramaximal loads by collection in two 180 liter Tissot spirometers of the expired air between the 4 th and 5 th and the 5 th and 6 th min, respectively, from exercise onset.

Computer analysis. To quantify the effect of a [2,3$\mathrm{DPG}] /[\mathrm{Hb}]$ change per se on the $\mathrm{O}_{2}$ supply to the muscles, a computer simulation was carried out based on known $[\mathrm{Hb}], \mathrm{V}_{2}$, and assumed gas pressure values of venous blood at rest and during maximal and supramaximal exercise $(17,19)$. In the simulation, for which a computer (PDP/11) program was worked out, the independent variable is $[2,3-\mathrm{DPG}] /[\mathrm{Hb}]$, which ranges by preset steps from 0.5 to 1.5. For each run, a given value for one-leg $\left(\dot{\mathrm{V}}_{2 \mathrm{~L}}\right)$ and pulmonary $\left(\dot{\mathrm{V}}_{2 \mathrm{P}}\right) \mathrm{O}_{2}$ uptake was chosen, together with appropriate values for arterial and venous blood gas pressures and for $[\mathrm{Hb}]$, and as a result a set of blood flow values was obtained reflecting the change of $[2,3-\mathrm{DPG}] /[\mathrm{Hb}]$ and, as a consequence, $\mathrm{Hb}-\mathrm{O}_{2}$ affinity. A lower flow value, all other variables being constant, would be indicative of an improved $\mathrm{O}_{2}$ transport to the tissues. The actual data used for the simulation appear in the legend of Fig. 3. They were obtained as follows. For leg blood flow $\left(\dot{Q}_{L}\right)$ actual data from the literature $(17,19)$ were used up to a $\mathrm{V}_{O_{L}}$ level of $1.17 \mathrm{l}$. $\min ^{-1}$; for $\mathrm{VO}_{2 \mathrm{~L}}=1.92 \mathrm{l} \cdot \mathrm{min}^{-1}, \mathrm{Po}_{2}, \mathrm{PCO}_{2}$, and $\mathrm{pH}$ values were obtained by extrapolation. For the latter work load the simulation was also made for conditions of metabolic acidosis (base excess $=-5$ and $-10 \mathrm{meq} \cdot \mathrm{l}^{-1}$, at constant $\left.\mathrm{PCO}_{2}\right)$. For cardiac output $\left(\dot{\mathrm{Q}}_{\mathrm{CO}}\right)$ actual data from the literature were adopted for $\mathrm{V}_{2} \mathrm{P}$ values up to $5.7 \mathrm{l} \cdot \mathrm{min}^{-1}$ $(9,19)$.

Statistics. Standard statistical procedures were adopted for the treatment of the results. Variance analysis was performed to assess the effects of training on the investigated variables. When significant differences were found (as indicated by the $F$ test), the comparison among means was made by the Newman-Keuls $Q$ method (28). Comparison between $\mathrm{C}$ and Sed was made by the unpaired $t$ test. The assumed significance level was $P<$ 0.05 .

\section{RESULTS}

Hematologic data. The physical characteristics and the standard hematologic data (avg RBC, $[\mathrm{Hb}]$, and Hct) of the athletes at the various training stages as well as the corresponding values for sedentary subjects are shown in Table 1 . Mean values $\left( \pm\right.$ SD) of experimental $P_{50}$, $[2,3-$ $\mathrm{DPG}] /[\mathrm{Hb}], \mathrm{pH}$ at $\mathrm{PCO}_{2}=42$ Torr and "normalized" $\mathrm{P}_{50}$ are shown in Table 2. In Fig. $1, A$ and $B$, individual values of $[2,3-\mathrm{DPG}] /[\mathrm{Hb}]$ and $\mathrm{P}_{50}$ are shown as a func- 
tion of training and are compared with the average data of sedentary subjects.

Hill's coefficient $n$ determined on five athletes in $\mathrm{CoS}$ conditions was $2.70 \pm 0.08$ (SD), i.e., not statistically

TABLE 2. [2,3-DPG]/[Hb], $\mathrm{PH}$, and $P_{50}$ in athletes and sedentary subjects

\begin{tabular}{lcccc}
\hline \hline & & & \multicolumn{2}{c}{$\mathrm{P}_{50}$, Torr } \\
\cline { 3 - 5 } Level of & $\begin{array}{c}{[2,3-\mathrm{DPG}] /[\mathrm{Hb}],} \\
\mathrm{mol} \cdot \mathrm{mol}^{-1}\end{array}$ & $\mathrm{pH}$ & Exptl & $\begin{array}{c}\text { Normal- } \\
\text { ized }\end{array}$ \\
\hline \multicolumn{5}{c}{ Athletes } \\
$\mathrm{C}$ & $0.72 \pm 0.03$ & $7.40 \pm 0.02$ & $27.0 \pm 0.8$ & 26.6 \\
$\mathrm{PrS}$ & $0.78 \pm 0.08$ & $7.42 \pm 0.02$ & $27.5 \pm 1.0$ & 27.0 \\
$\mathrm{CoS}$ & $0.95 \pm 0.07$ & $7.39 \pm 0.02$ & $27.8 \pm 1.6$ & 28.9 \\
& \multicolumn{3}{c}{ Sedentary subjects } \\
Sed & $0.85 \pm 0.05$ & $7.40 \pm 0.02$ & $27.5 \pm 0.9$ & 28.0 \\
\hline
\end{tabular}

Values are means \pm SD determined from venous blood of resting subjects. See footnote to Table 1 for level of activity. [2,3-DPG]/[Hb], 2,3-diphosphoglycerate-to-hemoglobin concentration ratio; $\mathrm{P}_{50}, \mathrm{Po}_{2}$ at which $\mathrm{Hb}$ is half-saturated with $\mathrm{O}_{2}$ (exptl: $\mathrm{PCO}_{2}=42$ Torr; normalized: calculated on means). different from the mean value $(2.65 \pm 0.08)$ found for the Sed subjects.

With the exception of $[2,3-\mathrm{DPG}] /[\mathrm{Hb}]$, which increased significantly $(P<0.001)$ with training, all other hematologic data were not significantly influenced either by the athletic condition or by heavy endurance training. $[2,3-\mathrm{DPG}] /[\mathrm{Hb}]$ and $[\mathrm{Hb}]$ differ significantly $(P<0.005$ and $P<0.01$, respectively) between athletes in $\mathrm{C}$ condition and Sed subjects.

Metabolic data. Table 3 summarizes the $\mathrm{V}_{0_{\max }}$, maximal heart rate $\left(\mathrm{HR}_{\max }\right)$, and maximal expiratory ventilation ( $\dot{\mathrm{V}}_{\max }$, i.e., $\dot{\mathrm{V} E}$ at $\dot{\mathrm{V}}_{\mathrm{O}_{2 \max }}$ ) data recorded in the bicycle racers at the different stages of training as well as the corresponding data for Sed subjects.

$\dot{\mathrm{VO}}_{2 \text { max }}$ increased significantly $(P<0.001)$ as a function of training both in absolute units $(7 \%)$ and when expressed per kilogram body weight $(9 \%)$ (see Fig. $1 C$ for individual values). $\dot{V} \mathrm{O}_{2 \max }$ in $\mathrm{CoS}$ was about $60 \%$ higher than the average value found for the group of sedentary subjects. $\mathrm{HR}_{\max }$ was lower $(P<0.001)$ in $\mathrm{C}$ athletes $(177$ \pm 8.7 beats $\left.\cdot \mathrm{min}^{-1}\right)$ than in $\operatorname{Sed}\left(192 \pm 6.2\right.$ beats $\left.\cdot \mathrm{min}^{-1}\right)$ and was not affected by training. $\dot{V} E_{\max }$ was greater $(P<$ $0.001)$ in $C$ athletes than in Sed $(134 \pm 29$ vs. $105 \pm 25$

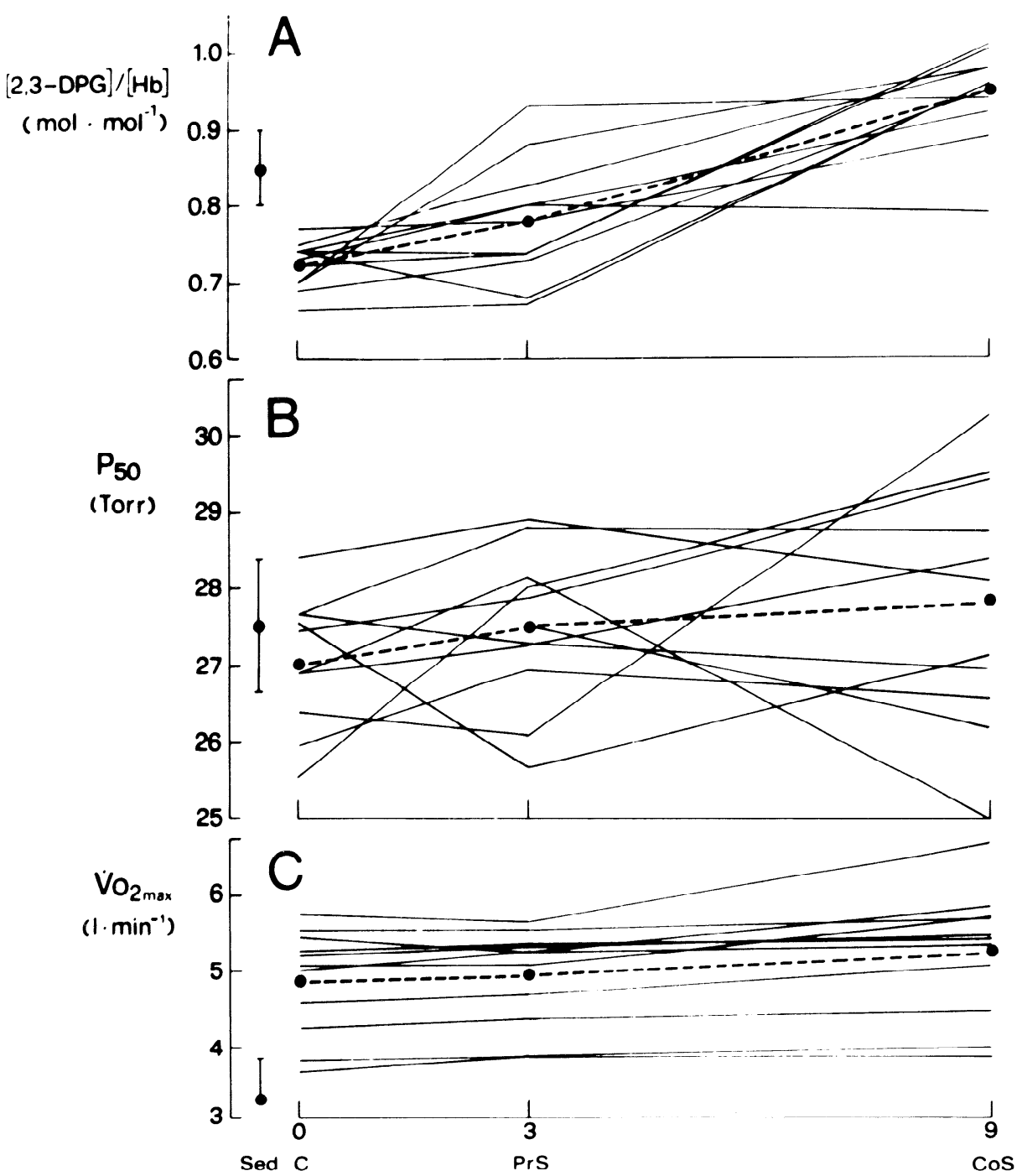

Time (months)
FIG. 1. Individual values of 2,3-diphosphoglycerate-to-hemoglobin concentration ratio ([2,3-DPG] $/[\mathrm{Hb}], A), \mathrm{O}_{2}$ half-saturation pressure $\left(\mathrm{P}_{50}, B\right)$, and maximal $\mathrm{O}_{2}$ consumption $\left(\mathrm{VO}_{2 \max }, C\right)$ in 11 elite bicycle racers at 3 different training levels. Dashed lines represent means. C, off-season (control); PrS, preseason; CoS, competitive season. Points on left $(\mathrm{Sed})$ are mean values $( \pm \mathrm{SD})$ for sedentary subjects. 
TABLE 3. Metabolic data of athletes and sedentary subjects

\begin{tabular}{|c|c|c|c|c|}
\hline \multirow{2}{*}{$\begin{array}{l}\text { Level of } \\
\text { Activity }\end{array}$} & \multicolumn{2}{|c|}{$\dot{\mathrm{V}} \mathrm{O}_{2 \max }$} & \multirow{2}{*}{$\begin{array}{l}\mathrm{HR}_{\max }, \\
\text { beats } \cdot \min \end{array}$} & \multirow{2}{*}{$\begin{array}{l}\dot{\mathrm{V}} \mathbf{E}_{\max }, \\
\mathrm{l} \cdot \mathrm{min}^{-1}\end{array}$} \\
\hline & $1 \cdot \min ^{-1}$ & $\underset{\mathrm{ml} \cdot \mathrm{kg}^{-1}}{\mathrm{~min}^{-1}}$ & & \\
\hline \multicolumn{5}{|c|}{ Athletes } \\
\hline $\mathrm{C}$ & $4.88 \pm 0.70$ & $68.1 \pm 10.3$ & $177 \pm 8.7$ & $134 \pm 29$ \\
\hline $\operatorname{PrS}$ & $4.94 \pm 0.65$ & $70.1 \pm 10.5$ & $175 \pm 9.4$ & $138 \pm 34$ \\
\hline $\mathrm{CoS}$ & $5.24 \pm 0.78$ & $74.5 \pm 9.5$ & $180 \pm 7.8$ & $152 \pm 30$ \\
\hline \multicolumn{5}{|c|}{ Sedentary subjects } \\
\hline Sed & $3.20 \pm 0.67$ & $45.8 \pm 8.3$ & $192 \pm 6.2$ & $105 \pm 25$ \\
\hline
\end{tabular}

Values are means \pm SD. See footnote to Table 1 for level of activity. $\dot{\mathrm{V}}_{2}$ max , maximal $\mathrm{O}_{2}$ consumption; $\mathrm{HR}_{\max }$, maximal heart rate; $\dot{\mathrm{V}}_{\mathrm{Emax}}$, maximal expiratory ventilation.

$\left.\mathrm{l} \cdot \mathrm{min}^{-1}\right)$ increasing with training $(\mathrm{CoS})$ to $152 \pm 30 \mathrm{l}$. $\min ^{-1}(P<0.001)$.

At submaximal work loads (i.e., between 150 and 300 W) a linear relationship between $\mathrm{Vo}_{2}$ and external power (W) was found in the athletes working on the bicycle, which for all training conditions is described by the following regression equation

$$
\dot{\mathrm{V}}_{2}\left(\mathrm{ml} \cdot \mathrm{min}^{-1}\right)=11.89 \dot{\mathrm{W}}+840 \quad(r=0.957)
$$

The calculated average efficiency $\eta$ (i.e., $\dot{\mathrm{W}} / \mathrm{V} \mathrm{O}_{2}$ ) was 0.24 . The $\dot{\mathrm{VE}}$ vs. $\mathrm{VO}_{2}$ relationship was essentially constant in the three experimental conditions.

\section{DISCUSSION}

Hematologic data and $\mathrm{O}_{2}$ equilibrium curve $(\mathrm{OEC})$. [Hb] is significantly lower in $\mathrm{C}$ than in Sed $(P<0.01)$, confirming previous observations by Brotherhood et al. (5) and Hunding et al. (16). RBC and Hct in the investigated group of bicycle racers were constant throughout the training period and did not differ from the values found in the sedentary control subjects. [2,3-DPG]/[Hb] increased 8 and $30 \%$ after 3 and 9 mo of training, respectively, in substantial agreement with previous studies in different types of athletes $(3,21,27)$. Whether this change is the response to a decreased venous $\mathrm{Hb}$ saturation (8), as may be the case for chronic hypoxia (25), is still matter for investigation.

The slight increase of the observed $\mathrm{P}_{50}$ as a function of training is not statistically significant but agrees with increased [2,3-DPG]/[Hb]. The lack of a closer correlation between the two above variables may be attributed to the variability of the method for the assessment of $\mathrm{P}_{50}$, which has a SD of \pm 0.33 Torr (24), the variability of the $\mathrm{P}_{50}$ within the same individual (30), changes of the mean corpuscular $\mathrm{Hb}$ concentration [MCHC, see Table $1(10,18)]$, and changes of other minor cofactors of $\mathrm{Hb}$ oxygenation, such as the concentration of various salts within the normal range.

The small differences between experimental and normalized $\mathrm{P}_{50}$ values found in all subjects are within the range of error of the methods used. Therefore, no other cofactor of $\mathrm{Hb}$ oxygenation need be implicated besides $\mathrm{H}^{+}, \mathrm{CO}_{2}$, and 2,3-DPG. This finding enables us to apply the analytical approach developed for a normal sedentary population by Winslow et al. (31) also to the trained cyclists.

Metabolic data. World-class professional bicyclists exhibit the highest $\dot{\mathrm{V}} \mathrm{O}_{2 \max }$ values per kilogram body weight ever found in endurance-trained athletes (1). The $\mathrm{Vo}_{2 \text { max }}$ of the 1982 world champion $\left(85.4 \mathrm{ml} \cdot \mathrm{kg}^{-1} \cdot \mathrm{min}^{-1}\right)$ is the highest value ever recorded in our laboratory. This value is lower than that of an Olympic champion of the $15-\mathrm{km}$ cross-country skiing race $\left(94 \mathrm{ml} \cdot \mathrm{kg}^{-1} \cdot \mathrm{min}^{-1}\right)$ reported by Åstrand and Rodahl (1) but somewhat higher than that recorded in our laboratory for the bicycle racer Merckx $\left(73 \mathrm{ml} \cdot \mathrm{kg}^{-1} \cdot \mathrm{min}^{-1}\right)$ and the Olympic cross-country skiing champion Nones $\left(77 \mathrm{ml} \cdot \mathrm{kg}^{-1} \cdot \mathrm{min}^{-1}\right)$, respectively (personal observations).

The use of the bicycle ergometer for the measurement of $\mathrm{VO}_{2 \max }$ could be considered inadequate, since it was previously shown $(2,15)$ to underestimate by $\sim 10 \%$ comparative treadmill estimates. To check this particular point in bicycle racers, 7 of the 11 athletes under investigation also performed a number of increasing loads on a treadmill up to $\dot{\mathrm{V}}_{2 \text { max }}$. The results of these experiments appear in Fig. 2 where the $\dot{V} E$ vs. $\dot{V} o_{2}(A)$ and the $\mathrm{HR}$ vs. $\mathrm{Vo}_{2}(B)$ relationships are plotted up to maximal loads. For given $\dot{V}_{O_{2}}$ levels, both $\mathrm{HR}$ and $\dot{V}_{\mathrm{E}}$ values were higher in the treadmill than in the bicycle test. $\mathrm{HR}_{\max }$ values were $179 \pm 9$ beats $\cdot \mathrm{min}^{-1}$ on the bicycle and 184 \pm 10 beats $\cdot \min ^{-1}$ on the treadmill. Correspondingly, $\dot{\mathrm{V}} \mathrm{o}_{2 \max }$ values were $5.34 \pm 0.26$ and $5.14 \pm 0.38 \mathrm{l} \cdot \mathrm{min}^{-1}$, respectively. Thus the measured $\mathrm{V}_{2 \max }$ of bicycle racers appears to be somewhat higher when assessed on the bike than when running, as previously found by Hagberg et al. (11). The difference $(+3.4 \%)$, though small and not statistically significant, indicates that the $\dot{\mathrm{V}}_{2 \text { max }}$ values
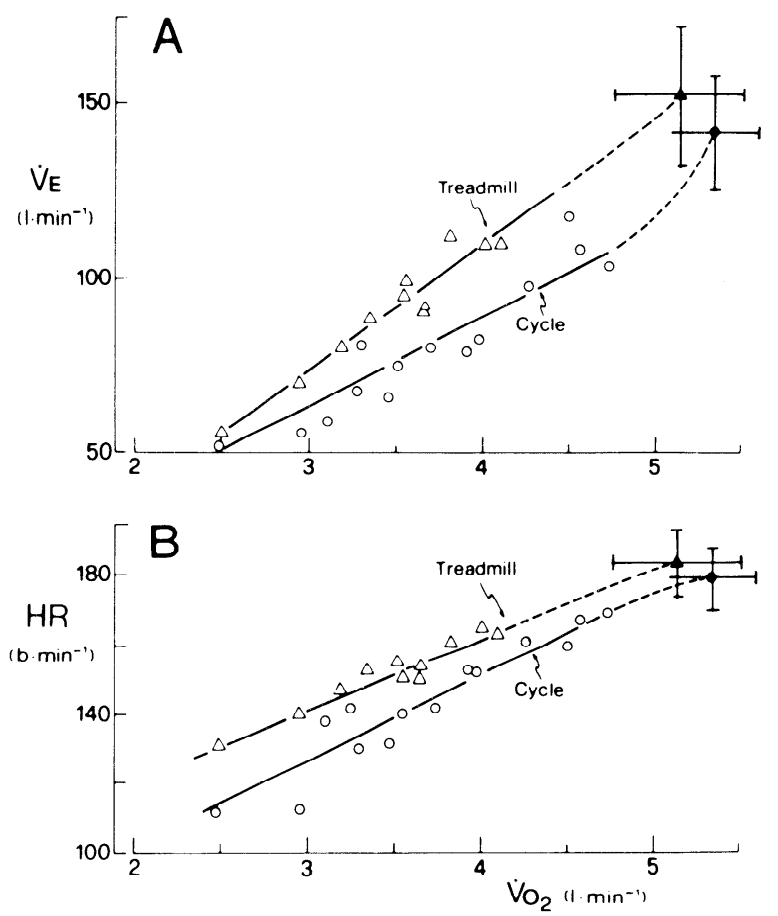

FIG. 2. Expiratory ventilation ( $\left.\dot{\mathrm{V}}_{\mathrm{B}^{\prime} \mathrm{TPS}}, A\right)$ and heart rate $(\mathrm{HR}, B)$ vs. $\mathrm{O}_{2}$ consumption $\left(\mathrm{V}_{2}\right)$ in 7 trained $(\mathrm{CoS})$ elite bicycle racers performing increasing work loads on both a cycle ergometer and a treadmill. Filled points $( \pm \mathrm{SD})$ indicate mean values obtained during performance of a supramaximal test. 
obtained in the present study represent a real maximum. The efficiency value $\eta$ of bicycle riding in laboratory conditions was the same $(0.24)$ in world-class athletes and in the group of sedentary subjects who volunteered for this study, being equal to the value given by Åstrand and Rodahl (1).

$\mathrm{VO}_{2 \max }$ measurements and their dependence on $\mathrm{O}_{2}$ affinity of blood. $\mathrm{O}_{2}$ delivery to working muscles may be enhanced after several months of training either as a consequence of increased [2,3-DPG]/[Hb] (see Table 2) or as a consequence of increased regional or overall blood flow. Increased [2,3-DPG]/[Hb] leads to a shift of the $\mathrm{OEC}$ to the right, thus enabling $\mathrm{Hb}$ for a given $\mathrm{Po}_{2}$ level

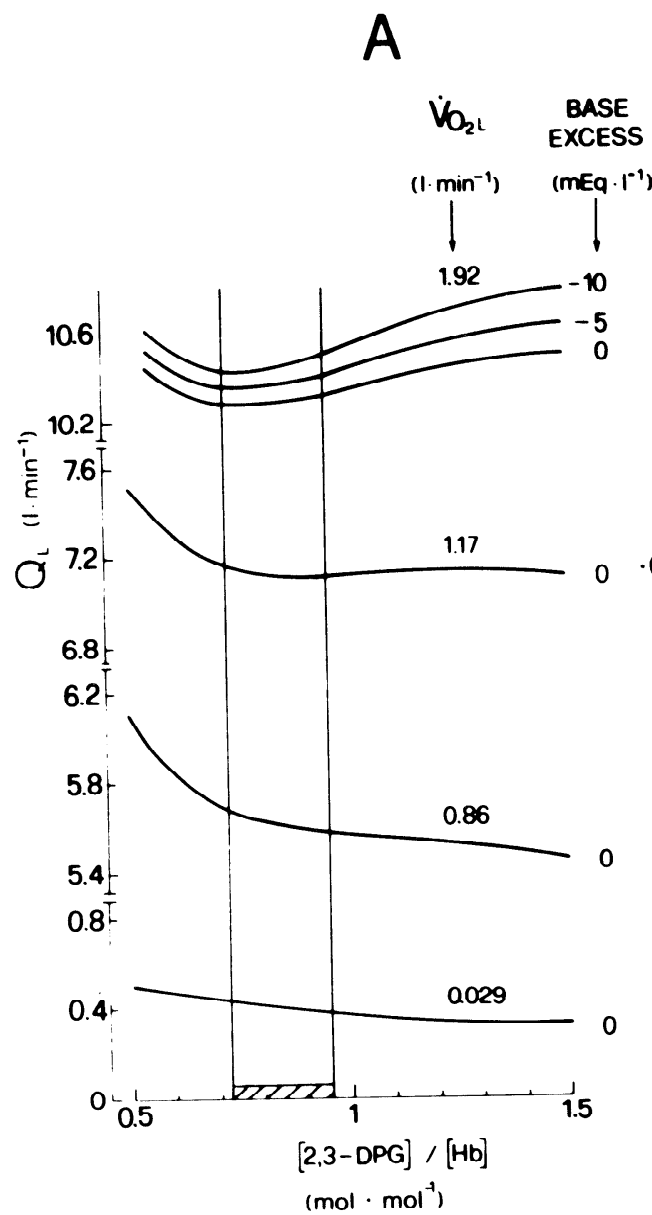

FIG. 3. Computer simulation of leg blood flow $\left(\dot{Q}_{\mathrm{L}}, A\right)$ and cardiac output $\left(\dot{\mathrm{Q}}_{\mathrm{Co}}, B\right)$ changes as a function of 2,3-diphosphoglycerate-tohemoglobin concentration ratio $\left([2,3-\mathrm{DPG}] /[\mathrm{Hb}], \mathrm{mol} \cdot \mathrm{mol}^{-1}\right)$. Each maximal $\mathrm{O}_{2}$ consumption $\left(\mathrm{V}_{\mathrm{O}_{2}}\right)$ value for a single leg $\left(\mathrm{V}_{\mathrm{O}_{2}}\right)$ shown in $A$ corresponds to pulmonary $\mathrm{O}_{2}$ uptake $\left(\mathrm{V}_{2} \mathrm{P}\right)$ value indicated in $B$. Range of $[2,3-\mathrm{DPG}] /[\mathrm{Hb}]$ marked with diagonal bars represents average to deliver more $\mathrm{O}_{2}$ to the working muscles. Since the analytical procedures for the assessment of the variables involved in the $\mathrm{Hb}-\mathrm{O}_{2}$ affinity are characterized by an unavoidable scatter, a straightforward answer to the above question cannot be given on a strictly experimental basis. Thus a computer simulation is proposed whereby $[2,3-\mathrm{DPG}] /[\mathrm{Hb}]$ is taken as the independent variable, all other cofactors of $\mathrm{Hb}$ oxygenation being constant. The selected algorithm allows blood flow values (local $\dot{Q}_{L}$, pulmonary $\dot{\mathrm{Q}}_{\mathrm{CO}}$ ) to be established for given $\mathrm{V}_{\mathrm{O}_{2}}$ levels. Changes of blood flow depend only on the changes of $[2,3-\mathrm{DPG}] /[\mathrm{Hb}]$, whereas the $\mathrm{P}_{50}$ values are the calculated ones that differ slightly from those measured ex-

B

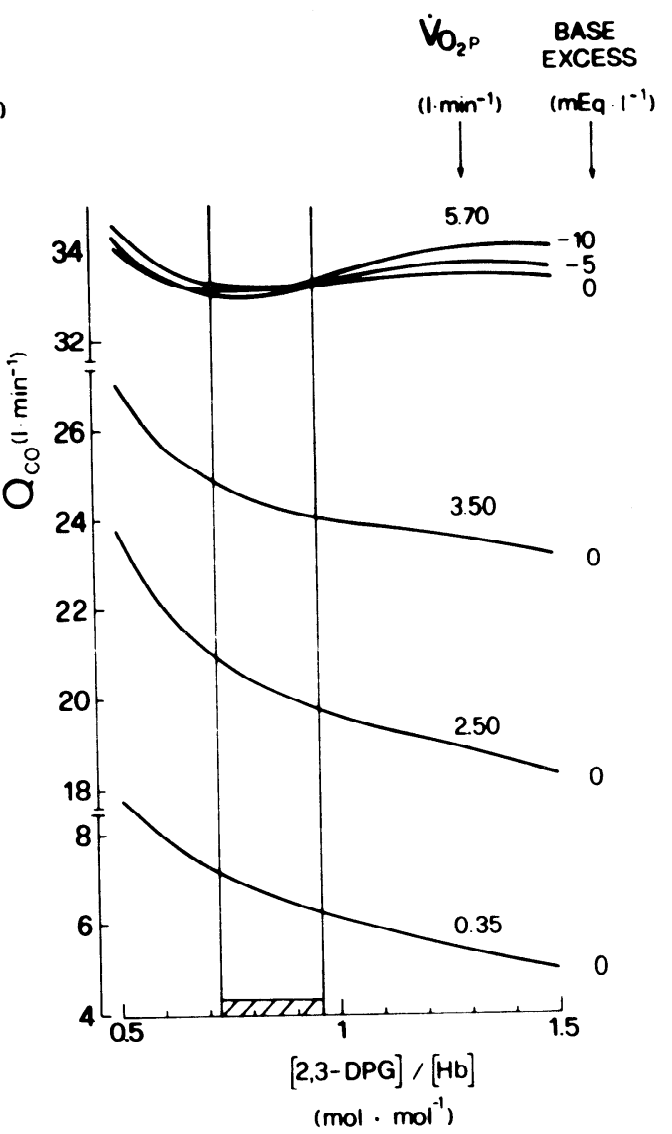

increase observed with training in investigated subjects (see Table 2). Besides an $[\mathrm{Hb}]$ of $15 \mathrm{~g} \cdot \mathrm{dl}^{-1}$, a temperature of $37^{\circ} \mathrm{C}$, constant arterial values for $\mathrm{PO}_{2}$ (90 Torr), $\mathrm{PCO}_{2}$ (42 Torr), and base excess (BE) values of $0(\mathrm{pH}=7.4),-5(\mathrm{pH}=7.32)$, and $-10 \mathrm{meq} \cdot \mathrm{l}^{-1}(\mathrm{pH}=7.24)$, the following metabolic and venous values were used for the simulation:

\begin{tabular}{|c|c|c|c|c|c|c|c|c|c|}
\hline \multirow{2}{*}{$\begin{array}{c}\dot{\mathrm{Vo}_{2}}, \\
\text { 1. } \min ^{-1}\end{array}$} & \multicolumn{3}{|c|}{ Venous Blood } & \multirow{2}{*}{$\begin{array}{c}\mathrm{BE}, \\
\text { neq } \cdot \mathrm{l}^{-1}\end{array}$} & \multirow{2}{*}{$\begin{array}{c}\dot{\mathrm{V} \mathrm{O}_{2}}, \\
1 \cdot \min ^{-1}\end{array}$} & \multicolumn{3}{|c|}{ Mixed Venous Blood } & \multirow{2}{*}{$\begin{array}{c}\mathrm{BE}, \\
\mathrm{meq} \cdot 1^{-1}\end{array}$} \\
\hline & $\begin{array}{l}\mathrm{Po}_{2} \text {, } \\
\text { Torr }\end{array}$ & $\begin{array}{l}\mathrm{PCO}_{2}, \\
\text { Torr }\end{array}$ & $\mathrm{pH}$ & & & $\begin{array}{l}\mathrm{Po}_{2}, \\
\text { Torr }\end{array}$ & $\begin{array}{l}\mathrm{PcO}_{2}, \\
\text { Torr }\end{array}$ & $\mathrm{pH}$ & \\
\hline \multicolumn{5}{|c|}{ A. Single-leg blood flow $\left(\dot{\mathrm{Q}}_{\mathrm{L}}, 1 \cdot \mathrm{min}^{-}\right.$} & \multicolumn{5}{|c|}{ B. Cardiac output $\left(\dot{\mathrm{Q}} \mathrm{co}, 1 \cdot \mathrm{min}^{-1}\right)$} \\
\hline 0.029 & 34 & 48 & 7.36 & 0 & 0.35 & 40 & 46 & 7.37 & 0 \\
\hline 0.86 & 18 & 62 & 7.30 & 0 & 2.50 & 24 & 57 & 7.33 & 0 \\
\hline 1.17 & 15 & 66 & 7.29 & 0 & 3.50 & 20 & 62 & 7.31 & 0 \\
\hline 1.92 & 7 & 72 & 7.20 & 0 & 5.70 & 13 & 66 & 7.29 & 0 \\
\hline 1.92 & 7 & 72 & 7.13 & -5 & 5.70 & 13 & 66 & 7.19 & -5 \\
\hline 1.92 & 7 & 72 & 7.07 & -10 & 5.70 & 13 & 66 & 7.12 & -10 \\
\hline
\end{tabular}


perimentally for the reasons given above (see Hematological data and $\mathrm{O}_{2}$ equilibrium curves). In particular, a drop of flow for a given set of conditions identifies an increased $\mathrm{O}_{2}$ supply to the tissues per unit volume of blood.

From Fig. 3 it appears that when $[2,3-\mathrm{DPG}] /[\mathrm{Hb}]$ increases from 0.72 to 0.95 , calculated $\mathrm{Q}_{\mathrm{L}}$ and $\mathrm{Q}_{\mathrm{CO}}$ in endurance athletes at metabolic levels around $\dot{V}_{o_{2 m a x}}$ are essentially constant. The results of the simulation that support the present experimental data are at variance with the conclusion of Braumann et al. (4), who claim that "physical training leads to an alteration of the $\mathrm{Hb}$ $\mathrm{O}_{2}$ affinity which is not explained by the influence of any known factor, resulting in an increased $\mathrm{O}_{2}$ extraction." The hypothesis that an increase of [2,3-DPG]/[Hb] may raise the maximal delivery of $\mathrm{O}_{2}$ to the working muscles appears therefore to be disproved. On the other hand, at lower metabolic levels and particularly at rest, increased $[2,3-\mathrm{DPG}] /[\mathrm{Hb}]$ appears to be associated with a decrease of both $\mathrm{Q}_{\mathrm{L}}$ and $\mathrm{Q}_{\mathrm{Co}}$. Correspondingly, for any given metabolic level, the same amount of $\mathrm{O}_{2}$ can be delivered to the tissues with less blood flow due to the rightward shift of the OEC with a proportional saving of myocardial work. This changing effect as a function of the metabolic level is the consequence of the peculiar shape of the OEC. In fact, at low $\mathrm{PO}_{2}$ values, a rightward shift of the OEC lowers $\mathrm{O}_{2}$ saturation markedly less than in the middle portion of the curve. This means that when venous $\mathrm{Po}_{2}$ is very low such as during maximal work, an increase of [2,3-DPG] at constant arterial $\mathrm{Po}_{2}$ can be of little advantage or even negative, because the decreased arterial $\mathrm{O}_{2}$

\section{REFERENCES}

1. Âstrand, P.-O., AND K. Rodahl. Textbook of Work Physiology. New York: McGraw-Hill, 1977. p. 321-408.

2. Åstrand, P.-O., AND B. SAltin. Maximal oxygen uptake and heart rate in various types of muscular activity. J. Appl. Physiol. 16: 977-981, 1961.

3. Braumann, K. M., D. Böning, and F. Trost. Oxygen dissociation curves in trained and untrained subjects. Eur. J. Appl. Physiol. Occup. Physiol. 42: 51-60, 1979.

4. Braumann, K. M., D. Böning, and F. Trost. Bohr effect and slope of the oxygen dissociation curve after physical training. $J$. Appl. Physiol.: Respirat. Environ. Exercise Physiol. 52: 1524-1529, 1982.

5. Brotherhood, J., B. Brozovic, and L. G. C. E. Pugh. Haematological status of middle- and long- distance runners. Clin. Sci Mol. Med. 48: 139-145, 1975.

6. Cerretelli, P., R. S. SiKAND, AND L. E. FARHI. Effect of increased airway resistance on ventilation and gas exchange during exercise. J. Appl. Physiol. 27: 597-600, 1969.

7. DEMPSEY, J. A. Relative significance of $\mathrm{HbO}_{2}$ dissociation curve shifts, in exercise and in chronic hypoxia. Physiologist 25: 89-90, 1982.

8. Duhm, J., AND E. Gerlach. On the mechanism of the hypoxiainduced increase of 2,3-diphosphoglycerate in erythrocytes. Pfluegers Arch. 326: 254-269, 1971.

9. Ekblom, B., ANd L. Hermansen. Cardiac output in athletes. $J$. Appl. Physiol. 25: 619-625, 1968.

10. FinCh, C. A., AND C. Lenfant. Oxygen transport in man. N. Engl. J. Med. 286: 407-415, 1972 .

11. HagberG, J. M., M. D. Giese, AND R. B. Schneider. Comparison of the three procedures for measuring $\mathrm{VO}_{2 \max }$ in competitive cyclists. Eur. J. Appl. Physiol. Occup. Physiol. 39: 47-52, 1978.

12. Henriksson, J. Training induced adaptation of skeletal muscle and metabolism during submaximal exercise. J. Physiol. London 270: 661-675, 1977.

13. Henriksson, J., AND J. S. ReITman. Quantitative measures of saturation (due to [2,3-DPG] increase) may exceed that of venous blood. A possible decrease of arterial $\mathrm{Po}_{2}$, and therefore of the arterial $\mathrm{O}_{2}$ saturation as found during extremely heavy exercise (7), could also contribute to negatively affect the curves at the top of Fig. $3, A$ and $B$. In fact, in the above conditions, increased [2,3-DPG]/ $[\mathrm{Hb}]$ would lead to a further rise of the calculated $\mathrm{Q}_{\mathrm{L}}$ and $\dot{\mathrm{Q}}_{\mathrm{co}}$, which leads to an increased load on the heart.

In conclusion, $\dot{\mathrm{V}}_{2 \max }$ absolute values rose $7 \%$ with maximal training. Based on the computer simulation such rise in maximal aerobic power cannot be attributed to an improved function of the $\mathrm{O}_{2}$ carrier consequential to the measured increase in $[2,3-\mathrm{DPG}] /[\mathrm{Hb}]$. Thus the present results can only be explained either by increased perfusion (increase of cardiac output and/or regional muscular blood flow) or by increased tissue $\mathrm{O}_{2}$ extraction, which would lead to lower venous blood $\mathrm{Po}_{2}$ levels. The latter change could be the consequence of an improved capillarization associated with an increased mitochondrial mass in the working muscles, which are known to occur in the course of endurance training (12-14).

The authors are indebted to A. Galimberti and E. Rossi of the Clinical Laboratory, Institute of Physiology, University of Milan, for part of the hematologic measurements.

Financial support from the Centro Studi di Fisiologia del Lavoro Muscolare del Consiglio Nazionale delle Ricerche, Milan (Italy) and Dept. of Basic Biomedical Sciences, University of Brescia (Italy) is also acknowledged.

Received 16 June 1983; accepted in final form 3 February 1984

enzyme activities in type I and type II muscle fibers of man after training. Acta Physiol. Scand. 97: 392-397, 1976.

14. Henriksson, J., AND J. S. Reitman. Time course of changes in human skeletal muscle succinate dehydrogenase and cytochrome oxidase activities and maximal oxygen uptake with physical activity and inactivity. Acta Physiol. Scand. 99: 91-97, 1977.

15. Hermansen, L., AND B. Saltin. Oxygen uptake during maximal treadmill and bicycle exercise. J. Appl. Physiol. 26: 31-37, 1969.

16. Hunding, G. A., R. Jordal, And P. E. Pauvel. Runner's anemia and iron deficiency. Acta Med. Scand. 209: 315-318, 1981.

17. JORFELDT, L., AND J. WAHREN. Leg blood flow during exercise in man. Clin. Sci. 41: 459-473, 1971.

18. LAver, M. B., E. Jackson, M. Scherperel, C. Tung, W. TUnG, AND E. P. RADFORD. Hemoglobin- $\mathrm{O}_{2}$ affinity regulation: DPG, monovalent anions, and hemoglobin concentration. J. Appl. Physiol.: Respirat. Environ. Exercise Physiol. 43: 632-642, 1977.

19. Pernow, B., J. Wahren, and S. ZetTerquist. Studies on peripheral circulation and metabolism in man. Acta Physiol. Scand. 64: 289-298, 1965.

20. Rand, P. W., J. M. Norton, N. Barker, And M. Lovell. Influence of athletic training on hemoglobin-oxygen affinity. Am. J. Physiol. 224: 1334-1337, 1973.

21. REMES, K., P. VUOPIO, AND M. HÄRKÖNEN. Effect of long-term training and acute physical exercise on red cell 2,3-diphosphoglycerate. Eur. J. Appl. Physiol. Occup. Physiol. 42: 199-207, 1979.

22. SAltin, B., AND L. Rowell. Functional adaptations to physical activity and inactivity. Federation Proc. 39: 1506-1513, 1980.

23. Samaja, M., D. Melotti, A. Carenini, and G. Pozza. Glycosylated haemoglobins and the oxygen affinity of whole blood. Diabetologia 23: 399-402, 1982.

24. Samaja, M., A. Mosca, L. Luzzana, L. Rossi-Bernardi, ANd R. M. WINSLOW. Equations and nomograms for the relationship of human blood $\mathrm{P}_{50}$ with 2,3-DPG and $\mathrm{H}^{+}$. Clin. Chem. 27: 1856-1861, 1981.

25. Samaja, M., A. Veicsteinas, And P. Cerretelli. Oxygen affinity 
of blood in altitude Sherpas. J. Appl. Physiol.: Respirat. Environ. Exercise Physiol. 47: 337-341, 1979.

26. Samaja, M., AND R. M. Winslow. The separate effects of $\mathrm{H}^{+}$and 2,3-DPG on the oxygen equilibrium curve of human blood. $B r . J$. Haematol. 41: 373-381, 1979.

27. Shappel, S. D., J. A. Murray, A. J. Bellingham, R. D. WoodSON, J. C. DETTER, AND C. LENFANT. Adaptation to exercise: role of hemoglobin affinity for oxygen and 2,3-diphosphoglycerate. $J$. Appl. Physiol. 30: 827-832, 1971.

28. Snenecor, G. W., and W. G. Cochran. Statistical Methods. Ames, IA: Iowa State Univ. Press, 1978.

29. Taunton, J. E., C. A. TAunton, AND E. W. Banister. Alterations in 2,3-DPG and $\mathrm{P}_{50}$ with maximal and submaximal exercise. Med. Sci. Sports 6: 238-241, 1974.

30. Winslow, R. M., J. M. Morrissey, R. L. Berger, P. D. Smith, AND C. C. GIBSON. Variability of oxygen affinity of normal blood: an automated method of measurement. J. Appl. Physiol.: Respirat. Environ. Exercise Physiol. 45: 289-297, 1978.

31. Winslow, R. M., M. Samaja, N. J. Winslow, L. Rossi-BerNARDI, AND R. L. Shrager. Simulation of continuous human blood $\mathrm{O}_{2}$ equilibrium curve over physiological $\mathrm{pH}, \mathrm{DPG}$, and $\mathrm{PCO}_{2}$ range. J. Appl. Physiol.: Respirat. Environ. Exercise Physiol. 54: 524-529, 1983.

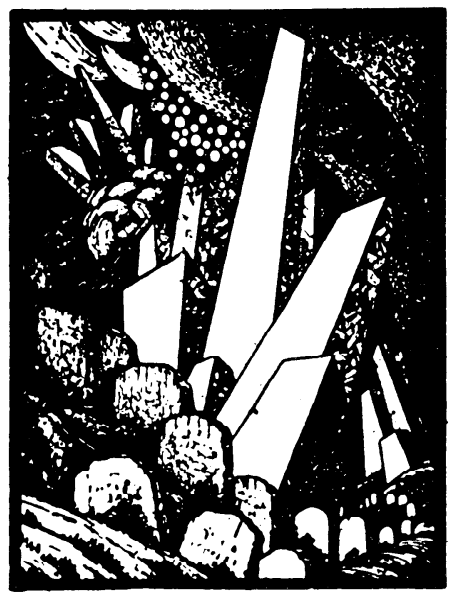

